\title{
American Cockroach, Periplaneta americana (Linnaeus) (Insecta: Blattaria: Blattidae) ${ }^{1}$
}

K. A. Barbara ${ }^{2}$

\section{Introduction}

The American cockroach, Periplaneta americana (Linnaeus), is the largest of the common peridomestic cockroaches measuring on average $4 \mathrm{~cm}$ in length. It occurs in buildings throughout Florida especially in commercial buildings. In the northern United States the cockroach is mainly found in steam heat tunnels or large institutional buildings. The American cockroach is second only to the German cockroach in abundance.

\section{Distribution}

Forty-seven species are included in the genus Periplaneta, none of which are endemic to the U.S. (Bell and Adiyodi 1981). The American cockroach (P. americana) was introduced to the United States from Africa as early as 1625 (Bell and Adiyodi 1981). The American cockroach has spread throughout the world by commerce. The cockroach is often found residing indoors as well as outdoors. It is found mainly in basements, sewers, steam tunnels, and drainage systems (Rust et. al. 1991). This cockroach is readily found in commercial and large buildings such as restaurants, grocery stores,

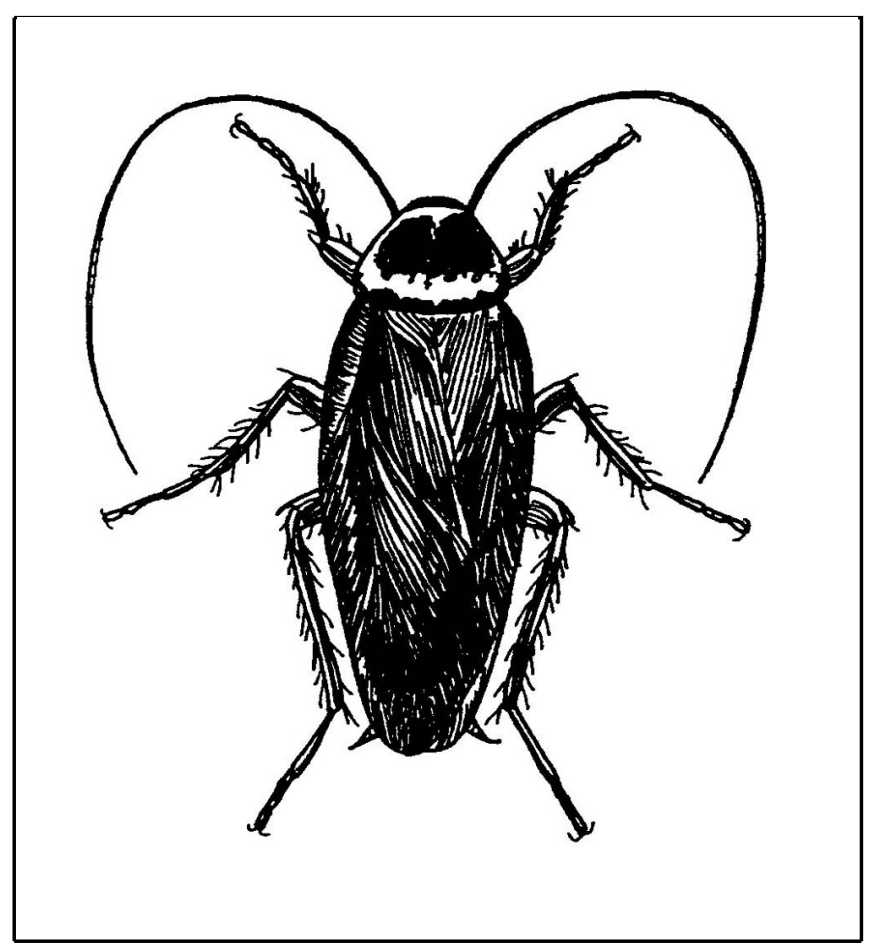

Figure 1. American cockroach adult. Credits: University of Florida

bakeries, and where food is prepared and stored. The American cockroach is rarely found in houses, however after heavy rain infestations of the cockroach can occur in homes. They can develop to

1. This document is EENY-141, one of a series of Featured Creatures from the Entomology and Nematology Department, Florida Cooperative Extension Service, Institute of Food and Agricultural Sciences, University of Florida. Published: June 2000. This document is also available on Featured Creatures Website at http://creatures.ifas.ufl.edu. Please visit the EDIS Website at http://edis.ifas.ufl.edu. Additional information on these organisms, including many color photographs, is available at the Entomology and Nematology Department WWW site at http://entnemdept.ifas.ufl.edu/.

2. K. A. Barbara, Entomology and Nematology Department, University of Florida, Insititute of Food and Agricultural Sciences, Gainesville, FL 32611.

The Institute of Food and Agricultural Sciences is an equal opportunity/affirmative action employer authorized to provide research, educational information and other services only to individuals and institutions that function without regard to race, color, sex, age, handicap, or national origin. For information on obtaining other extension publications, contact your county Cooperative Extension Service office. Florida Cooperative Extension Service/Institute of Food and Agricultural Sciences/University of Florida/Christine Taylor Waddill, Dean. 
enormous numbers, greater than 5,000 sometimes being found in individual sewer manholes (Rust et. al. 1991).

American cockroaches are found in moist shady areas outdoors, in yards, hollow trees, wood piles, and mulch. They are occasionally found under roof shingles and in attics. The cockroaches dwell outside but will wander indoors for food and water or during extremes in weather conditions. In Florida, areas such as trees, woodpiles, garbage facilities, and accumulations of organic debris around homes provide adequate food, water, and harborages for peridomestic cockroaches such as the American cockroach (Hagenbuch et al. 1988). Mass migrations of the American cockroaches are common (Ebeling 1975). They migrate by crawling or flying into structures often entering houses and apartments from sewers via the plumbing, by trees and shrubs located alongside buildings or trees with branches overhanging roofs facilitate the entry of cockroaches into the home. During the day the American cockroach, which responds negatively to light, rests in harborages close to water pipes, sinks, baths, and toilets, for example, where the microclimate is suitable for survival (Bell and Adiyodi 1981).

\section{Description}

\section{Egg}

Females of the American cockroach lay their eggs in a hardened, purseshaped egg case called an ootheca. About one week after mating the female produce an ootheca and at the peak of her reproductive period, she may form about two ootheca per week (Bell and Adiyodi 1981). The females on average produce an egg case about once a month for ten months laying 16 eggs per egg case. The female deposits the ootheca near a source of food by either simply dropping it or gluing it to a surface with a secretion from her mouth. The deposited ootheca contains water sufficient for the eggs to develop without receiving additional water from the substrate (Bell and Adiyodi 1981). The egg case is brown when deposited and turns black in a day or two. A typical egg case contains about 14 to 16 eggs. It is about 8 $\mathrm{mm}$ long and $5 \mathrm{~mm}$ high.

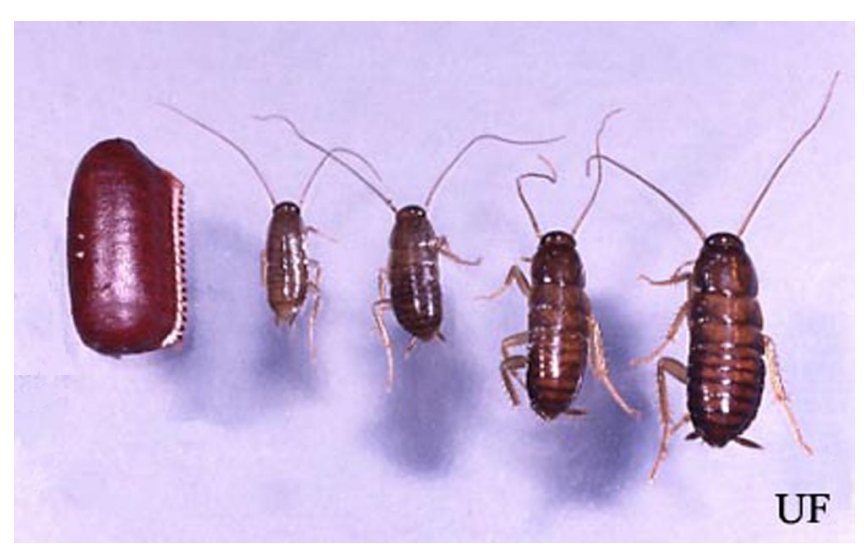

Figure 2. Ootheca and first, second, third and fourth instar nymphs of the American cockroach, Periplaneta americana (Linnaeus). Credits: Paul M. Choate, University of Florida

\section{Larva or Nymph}

The nymphal stage begins when the egg hatches and ends with the emergence of the adult. The number of times an American cockroach molts varies from six to 14 (Bell and Adiyodi 1981). The first instar American cockroach is white immediately after hatching then becomes a grayish brown. After molting instars of the cockroach nymphs are white and then become a uniformly reddish-brown with the posterior margins of the thoracic and abdominal segments being a darker color. Wings are not present in the nymphal stages and wig pads become noticeable in the third or fourth instar. Complete development from egg to adult is about 600 days. The nymphs as well as the adults actively forage for food and water.

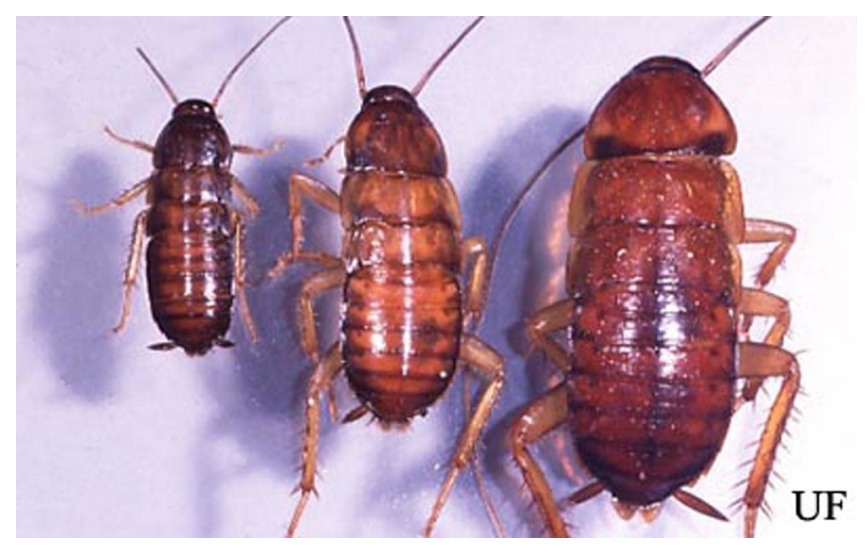

Figure 3. Fifth, sixth and seventh instar nymphs of the American cockroach, Periplaneta americana (Linnaeus). Credits: Paul M. Choate, University of Florida 


\section{Adult}

The adult American cockroach is reddish brown in appearance with a pale-brown or yellow band around the edge of the pronotum. The males are longer than the females because their wings extend 4 to $8 \mathrm{~mm}$ beyond the tip of the abdomen. Males and females have a pair of slender, jointed cerci at the tip of the abdomen. The male cockroaches have cerci with 18 to 19 segments while the female has 13 to 14 segments. The male American cockroaches have a pair of styli between the cerci while the females do not.

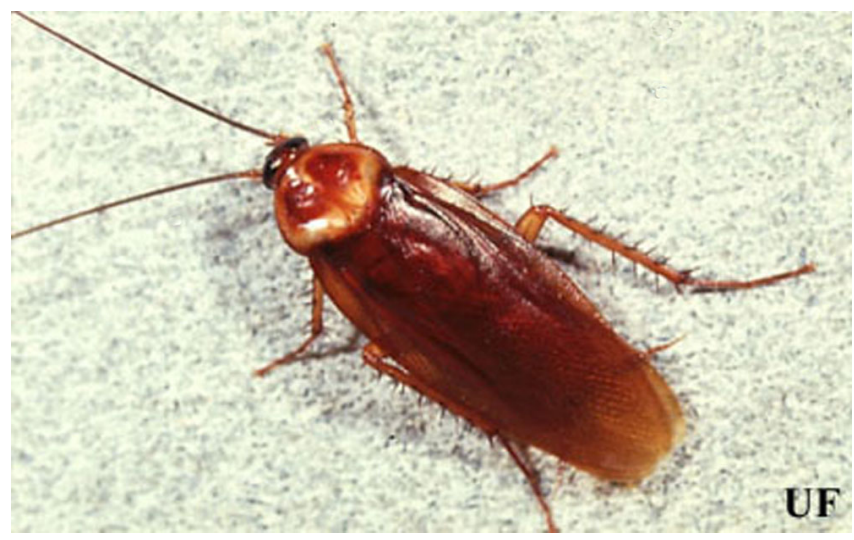

Figure 4. American cockroach, Periplaneta americana (Linnaeus), adult. Credits: James Castner, University of Florida

\section{Life Cycle}

The American cockroach has three life stages: the egg, a variable number of nymphal instars, and adult. The life cycle from egg to adult averages about 600 days while the adult life span may be another 400 days. The immatures emerge from the egg case in about six to eight weeks and mature in about six to twelve months. Adults can live up to one year and an adult female will produce an average of 150 young in her lifetime. Environmental factors such as temperature and humidity can increase or decrease the developmental time of the American cockroach. Outdoors the female shows a preference for moist, concealed ovipositon sites (Bell and Adiyodi 1981).

\section{Diet}

The American cockroach is an omnivorous and opportunistic feeder. It consumes decaying organic matter but since the cockroach is a scavenger it will eat most anything. It prefers sweets and has been observed eating paper, boots, hair, bread, fruit, book bindings, fish, peanuts, old rice, putrid sake, the soft part on the inside of animal hides, cloth and dead insects (Bell and Adiyodi 1981).

\section{Medical and Economic Significance}

American cockroaches can become a public health problem due to their association with human waste and disease, and their ability to move from sewers into homes and commercial establishments. In the United States during the summer, alleyways and yards maybe overrun by these cockroaches. The cockroach is found in caves, mines, privies, latrines, cesspools, sewers, sewerage treatment plants, and dumps (Bell and Adiyodi 1981). Their presence in these habitats is of epidemiological significance. At least 22 species of pathogenic human bacteria, virus, fungi, and protozoans, as well as five species of helminthic worms, have been isolated from field collected American cockroaches (Rust et. al. 1991). Cockroaches are also aesthetically displeasing because they can soil items with their excrement and regurgitation.

\section{Management}

Several hymenopteran natural enemies of the American cockroach have been found (Suiter et. al. 1998). These parasitic wasps deposit their eggs in the cockroach ootheca preventing the emergence of cockroach nymphs.

Caulking of penetrations through ground level walls, removal of rotting leaves, and limiting the moist areas in and around a structure can help in reducing areas that are attractive to these cockroaches.

Other means of management are insecticides that can be applied to basement walls, wood scraps, and other infested locations. Residual sprays can be applied inside and around the perimeter of an infested structure. When insecticides and sprays are used to manage cockroach populations they may ultimately kill off the parasitic wasps. Loose, toxic, pellet baits are extremely effective in controlling America cockroach populations. 


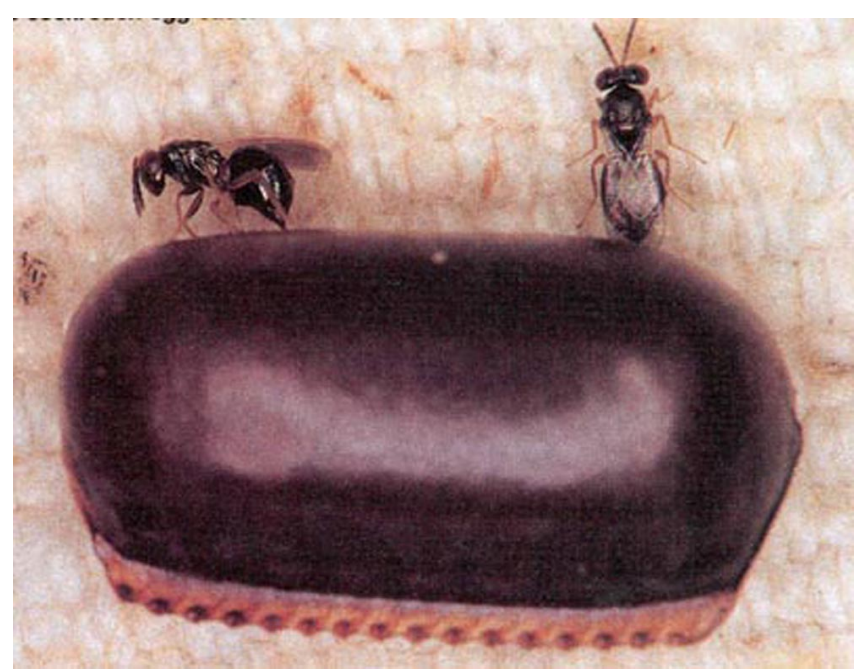

Figure 5. Aprostocetus hagenowii (Ratzeburg) is one of several parasitic wasps that attack American cockroach, Periplaneta americana (Linnaeus), oothecae. Credits: Pest Control magazine (used with permission)

For more information, see:

Insect Management Guide for Cockroaches

Least Toxic Methods of Cockroach Control

\section{Selected References}

Bell, WJ and KG Adiyodi. 1981. The American cockroach. Chapman and Hall, London.

Ebeling, W. 1975. Urban Entomology. University of California, Richmond, CA.

Hagenbuch, B.E., P.G. Koehler, R.S. Patterson, and R.J. Brenner. 1988. Peridomestic cockroaches (Orthoptera: Blattidae) of Florida: their species composition and suppression. J Med Entomol. 25(5):377-380.

Rust, M.K., D.A. Reierson, and K.H. Hansgen. 1991. Control of American cockroaches (Dictyoptera: Blattidae) in sewers. J Med Entomol. 28(2): 210-213.

Shaheen, L. 2000. Environmental protection comes naturally. Pest Control. 68: 53-56.

Suiter, D.R.. 1997. Biological suppression of synanthropic cockroaches. J Agric Entomol. 14: 259-270.
Suiter, D.R., R.S. Patterson, and P.G. Koehler. Seasonal incidence and biological control potential of Aprostocetus hagenowii (Hymenoptera: Eulophidae) in treehole microhabitats. J Eviron Entomol. 27: 434-442.

Valles, S. (September 1996). German cockroach, Blatella germanica (Linnaeus). UF/IFAS Featured Creatures. EENY-002. http://edis.ifas.ufl.edu/IN128 (June 2000). 